salts. The conidia were harvested in saline containing 0.1 per cent calzolene oil and were counted in a hæmocytometer. They were precipitated with $0 \cdot 5$ vol. 30 per cent trichloroacetic acid and extracted successively with 10 per cent trichloroacetic acid (twice), acetone, ethanol, hot ethanol : chloroform $3: 1$, hot ethanol : ether $3: 1$ (twice) and ether. The dry powder obtained was extracted ${ }^{\theta}$ with 5 per cent trichloroacetic acid at $90^{\circ}$ for $15 \mathrm{~min}$., and the deoxypentose in the extract was estimated by the diphenylamine method ${ }^{10}$ with incubation at $37^{\circ}$ for $18 \mathrm{hr}$. The results are expressed in terms of deoxyribonucleic acid phosphorus, the method having been calibrated with purified thymus deoxyribonucleic acid.

$\begin{array}{cc}\text { Strain } & \begin{array}{c}\text { Deoxyribonucleic acid phosphorus } \\ \left(10^{-12} \mathrm{gm} .\right.\end{array} \\ \text { Green haploid } & 4 \cdot 04 \\ \text { Green diploid } & 9 \cdot 39 \\ \text { White haploid } & 4 \cdot 22 \\ \text { White diploid } & 7 \cdot 75\end{array}$

Within the limits of the methods, these figures are consistent with a deoxyribonucleic acid ratio of $1: 2$ for the conidia from haploid and diploid strains.

Department of Biochemistry and F. C. HEAGY* J. A. ROPER Department of Genetics,

University, Glasgow, W.2. July 17.

* British Empire Cancer Campaign Exchange Fellow.

${ }^{1}$ Boivin, A., Vendrely, R., and Vendrely, C., C.R. Acad. Sci., Paris, 226, 1061 (1948).

${ }^{2}$ Davidson, J. N., and Leslie, I., Cancer Res., 10, 587 (1950),

${ }^{8}$ Mirsky, A. E., and Ris, H., J. Gen. Physiol., 34, 451 (1951).

Thomson, R. Y., Heagy, F. C., Hutchison, W. C., and Davidson, J. N. (to be published).

${ }^{5}$ Roper, J. A., Experientia, 8, 14 (1952).

"Pontecorvo, G., and Roper, J. A., "Advances in Genetics", 5 (in the press).

Yuill, E., J. Bot., r7, 174 (1939).

${ }^{8}$ Pontecorvo, G., and Koper, J. A., J. Gen. Microbiol. (Proc.), 6. vii (1952).

- Schneider, W. C., J. Biol. Chem., 161, 293 (1945). ${ }^{10}$ Patterson, E. K., and Dackerman, M. W., Arch. Biochem. Biophys.,
36, 97 (1952).

\section{Efficiency of Growth in Mytilus edulis and Two Gastropod Veligers}

GRowTH efficiencies have been studied extensively in domestic animals and in some common laboratory animals ${ }^{1}$. Little is known, however, of the utilization of energy in the growth of lower animals. I have been able to show that marine invertebrates may have high growth efficiencies. Efficiency calculations were based on growth-rate and oxygen uptake in Mytilus edulis of different ages, and in veligers of two marine gastropods, Littorina littorea and Nassa reticulata. Rates of growth were calculated from average increases in length in Nature during known intervals of time. Data published by Thorson ${ }^{2}$ were used in calculating growth-rates of veligers of Littorina and Nassa (from the Isefjord, Denmark) and of young metamorphosed Mytilus (from the Sound). I myself measured the growth of Mytilus veligers (from Isefjord). Data on growth of Mytilus during later stages were obtained from the Pacific off La Jolla, California, where $\mathrm{Coe}^{3}$ measured the average increment in length of different age- and size-groups during August-November while maximum growth is taking place. Lengths were first converted into total nitrogen content using the relationship found by Zeuthen $^{4}$ (and unpublished results of Dr. Zeuthen). Then total organic matter was computed, assuming a nitrogen content of 8 per cent of the dry

\begin{tabular}{|c|c|c|c|c|c|}
\hline & $\begin{array}{l}\text { Length } \\
\text { (mm.) }\end{array}$ & $\begin{array}{c}\text { Nitrogen } \\
\text { content } \\
(\gamma \text {-nitrogen })\end{array}$ & $\begin{array}{c}\text { Daily } \\
\text { increase } \\
\text { in } \\
\text { organic } \\
\text { matter } \\
\text { (per } \\
\text { cent) }\end{array}$ & $\begin{array}{l}\text { Daily } \\
\text { com- } \\
\text { bustion } \\
\text { of } \\
\text { organic } \\
\text { matter } \\
\text { (per } \\
\text { cent) }\end{array}$ & $\begin{array}{l}\text { Gross } \\
\text { eff- } \\
\text { ciency } \\
\text { of } \\
\text { growth } \\
\text { (per } \\
\text { cent) }\end{array}$ \\
\hline $\begin{array}{l}\text { Mytilus } \\
\text { edulis } \\
\text { veliger }\end{array}$ & $0.00-0 \cdot 26$ & $0.003-0.07$ & $11 \cdot 2$ & $4 \cdot 2$ & 73 \\
\hline $\begin{array}{l}\text { Mytilus } \\
\text { edulis } \\
\text { meta- } \\
\text { morph- } \\
\text { osed }\end{array}$ & $\begin{array}{l}0 \cdot 35-6 \cdot 0 \\
17 \cdot 0-22 \cdot 3 \\
21 \cdot 0-32 \cdot 1 \\
31 \cdot 0-40 \cdot 9 \\
40 \cdot 9-49 \cdot 0 \\
51 \cdot 0-56 \cdot 9 \\
61 \cdot 0-63 \cdot 8 \\
90 \cdot 0-90 \cdot 8\end{array}$ & $\begin{array}{r}0 \cdot 2-100 \\
530-2,900 \\
2,500-7,000 \\
6,500-12,000 \\
12,000-18,500 \\
21,000-27,000 \\
32,000-36,000 \\
82,000-84,000\end{array}$ & $\begin{array}{r}14 \cdot 4 \\
5 \cdot 7 \\
3 \cdot 4 \\
2 \cdot 0 \\
1 \cdot 4 \\
0 \cdot 8 \\
0 \cdot 4 \\
0 \cdot 1\end{array}$ & $\begin{array}{l}2 \cdot 8 \\
1 \cdot 8 \\
1 \cdot 5 \\
1 \cdot 3 \\
1 \cdot 2 \\
1 \cdot 0 \\
1 \cdot 0 \\
0 \cdot 8\end{array}$ & $\begin{array}{l}84 \\
76 \\
69 \\
61 \\
54 \\
44 \\
29 \\
11\end{array}$ \\
\hline $\begin{array}{l}\text { Littorina } \\
\text { littorea } \\
\text { veliger }\end{array}$ & $0.20-0.38$ & $0 \cdot 02-0 \cdot 22$ & $9 \cdot 0$ & $5 \cdot 4$ & 62 \\
\hline $\begin{array}{l}\text { Nassa } \\
\text { reticu- } \\
\text { lata } \\
\text { veliger }\end{array}$ & $0 \cdot 30-0 \cdot 56$ & $0 \cdot 13-0 \cdot 63$ & $9 \cdot 3$ & $5 \cdot 4$ & 63 \\
\hline
\end{tabular}

organic matter. Rates of oxygen uptake were obtained from Zeuthen ${ }^{4}$. The oxygen values were converted into organic matter by assuming that 1.2 litres of oxygen is equivalent to $1 \mathrm{gm}$. of organic matter.

From the accompanying table it is seen that the efficiency of growth is of the same order in veligers of Mytilus, Littorina and Nassa. Furthermore, the efficiency of growth in Mytilus does not significantly change on metamorphosis. Owing to the heterogeneity of the material the increase in efficiency indicated in the table is probably not significant. A pronounced decrease in efficiency starts at a length of about $30 \mathrm{~mm}$., when the growth-rate drops to about 2 per cent daily. Harvey ${ }^{5}$ calculated that the efficieney of growth in the marine copepod Calanus finmarchicus was about 70 per cent. The growth efficiencies in Calanus, Littorina, Nassa and Mytilus, up to a length of about $50 \mathrm{~mm}$., fall close to the values found in embryos. The gross efficiencies of growth of embryos for the hen, frog, fish and silkworm are $62,51,59$ and 65 per cent, respectively (Brody ${ }^{1}$, pp. 43-44). Maximum efficiencies of postnatal growth are generally found to be lower than in these marine invertebrates ; for example, 20-40 per cent in pig, trout and cockroach ${ }^{6}$.

Zoophysiological Laboratory,

C. BARKER JøRGENSEN

University of Copenhagen. April 8.

"Brody, S., "Bioenergetics and Growth" (New York, 1945). Thorson, G., Medd. Komm. Danmarks Fisk.- og Havunders., Serie :
Plankton, 4 (1946).

${ }^{3}$ Coe, W. R., J. Exp. Zool., 99 (1945).

${ }^{4}$ Zeuthen, E., C.R. Lab. Carlsberg, Sér. chim., 28 (1947).

${ }^{5}$ Harvey, H. W., J. Mar. Biol. Assoc., 29 (1950).

${ }^{\circ}$ Rahn, O., Grouth, 4 (1940).

\section{Molybdenum Deficiency in Florida Citrus}

INvESTIGATIONS at this Station have disclosed that molybdenum deficiency is found in citrus trees throughout the citrus-growing area of Florida. The symptom of this deficiency has been called yellow spot since it was first described by Floyd ${ }^{1}$ in 1908. Yellow spot has also been reported in citrus on the Isle of Pines ${ }^{2}$. Repeated studies ${ }^{3}$ failed to demonstrate that it was due to an infectious fungus, bacterium or virus. It is known to occur on practically all kinds of citrus"; but the rootstock greatly affects the extent 